\title{
Wet-Nursing and Political Participation
}

The Republican Approaches to Motherhood of Mary Wollstonecraft and Sophie de Grouchy

Sandrine Bergès

DOI:10.1093/acprof:oso/9780198766841.003.0012

\begin{abstract}
Keywords
Caring duties, which fall particularly to women, are not always compatible with the degree of public life that republican citizenship requires. This is sometimes held as a feminist objection to republicanism. This chapter addresses this objection by focusing on the case of the mothering of infants and wet-nursing in the writings of Wollstonecraft and de Grouchy, two feminist writers of the Enlightenment period. It argues that both writers believe that mothering is central to the development of republican values and that compassion enables the growth of republican sentiments. But for Wollstonecraft this is a double-edged sword. For women to earn the status of citizens they must, if they are mothers, perform all duties attending to motherhood, including breastfeeding their children. Unfortunately, it is those duties that conflict with republican citizenship. A comparison with de Grouchy's own views on wet-nursing will point to a possible solution.
\end{abstract}

Keywords: Wollstonecraft, republicanism, Sophie de Grouchy, mothering, wet-nursing, care 
There is a well-known antagonism between feminists and republicanism such that feminist philosophers have been reluctant to embrace the growing trend for reviving various aspects of republican thinking. One way to phrase this antagonism is this: caring duties, which fall particularly to women, are not always compatible with the degree of public life and political participation that republican citizenship seems to require. ${ }^{1}$ More precisely, this can be taken to mean two related things. First, the republican emphasis on participation to acquire the full status of citizen makes it harder for women who have less leisure to take part in public life because they have duties inside the home. Secondly, it looks as if republicanism fails to give proper consideration to values that tend to be more represented in the female part of the population, such as caring for children, the elderly, and invalids, and instead, it tends to prefer values such as independence, which are more typically associated with men's experience.

There are two strands to the republican revival, which are very often brought together in some combination or other. ${ }^{2}$ Neo-Roman republicanism derives its (p.202) influence mostly from Roman ideals and its focus point is the definition of liberty as non-domination. It uses as its paradigmatic case the example of slavery: to be a slave is to be subject to arbitrary domination by a master; even if that master is benevolent, one is always at risk of being interfered with. ${ }^{3}$ Civic republicanism, on the other, hand, focuses on the Aristotelian ideals of participation and civic virtues. Its premise is that for human beings to flourish, they must participate in political life and that to do so successfully, they need to develop certain character traits such as virtues. ${ }^{4}$ It is this second strand, rather than the first, which proves problematic from the point of view of feminism. ${ }^{5}$ Civic virtues are often modelled on an Aristotelian model, and their focus is on public life, active participation rather than on the work that takes place in private but that is equally necessary in order to sustain the city: bringing up children, caring for the sick, etc.

Mary Wollstonecraft has recently been brought forward as a republican in the first sense thanks to her emphasis on the arbitrary nature of the power that men exercise over women, and her description of the effect that taking away women's liberty will have on their development and their capacity to become citizens. Yet, Wollstonecraft also discusses civic virtues, and in particular, she recognizes that bringing up children, first to be healthy, and secondly to develop the virtues necessary in a good citizen is a valuable form of participation, one that ought to earn mothers the right of citizenship. At the same time, her stance brings up the following worry: must participation for women depend on their willingness to be mothers? Shouldn't women be granted the rights of citizenship on the same basis as their male counterparts? 
In this chapter I explore the relationship between mothering and republican virtues with respect to Mary Wollstonecraft as well as another eighteenthcentury author, Sophie De Grouchy. I argue that taken together, their views can help us reconcile feminist and republican ideals to some extent. I will argue that both writers believe that mothering is central to the development of republican virtues: the early development of affections in a child, leading to the faculty of compassion, enables the growth of the republican sentiments of equality and fraternity. It is also noteworthy that for Wollstonecraft making mothering central to republicanism is a double-edged sword. For women to earn the status of citizens, (p.203) Wollstonecraft says, they must, if they are mothers, perform all duties attending to motherhood, including breastfeeding their children. Unfortunately, it is those mothering duties which I suggested could enter into conflict with republican citizenship. A comparison with de Grouchy's own views on wet-nursing will point to a possible solution.

\subsection{Wollstonecraft on Republican Mothering}

Despite her emphasis on the thought that, as far as their capacity for reason and virtue is concerned, men and women are equal and her vehement disagreement with Rousseau as to whether virtue can be relative to gender throughout the first part of her 'Animadversions', Wollstonecraft appears to demand a different sort of virtue for women in exchange for citizenship. ${ }^{6}$ In this section, I recommend caution in drawing that conclusion. Though some passages clearly suggest such an intention on her part, others are more tentative and lend themselves to a different interpretation altogether. Several passages strongly suggest that Wollstonecraft is adopting different requirements for men and women to attain citizenship: 'The wife, in the present state of things, who is faithful to her husband, and neither suckles nor educates her children, scarcely deserves the name of a wife and has no right to that of a citizen'. ${ }^{7}$ A little later she tells us that 'the care of children in their infancy is one of the grand duties annexed to the female character by nature', and again that 'the rearing of children [...] has justly been insisted on as the peculiar destination of woman'. 8 
Is Wollstonecraft saying that women are essentially better fitted to parenting duties than men, and that therefore their civic duties and virtues must be different? This would be going back on her claims that virtue must be the same for men and women. If virtue is based on reason, and reason is gender-neutral, then it is difficult to imagine how women's virtue can be radically different from men's. Wollstonecraft states clearly that she believes virtue arises from the exercise of reason at the beginning of the Vindication of the Rights of Woman, when she says that 'from the exercise of reason, knowledge and virtue naturally flow, is equally undeniable'. ${ }^{9}$ She further argues that this capacity for becoming virtuous cannot be either weaker or absent in women, as this would mean that God had created half of humanity as incapable of worshipping him. ${ }^{10}$ Whether or (p.204) not this is a good argument (and in fact, Wollstonecraft finds other ways of making similar points throughout the book ${ }^{11}$ ) it makes clear her commitment to virtue equality across the sexes. But equality can still entail difference: one could argue that a man who goes to work and a woman who cares for children are equally virtuous relative to their nature. But if, as Wollstonecraft argues, virtue is derived from reason, and not any other aspect of our nature, such as the ability to make and feed babies, then this does not follow. Reason is universal, therefore, so must virtue be. ${ }^{12}$

Rather than accuse Wollstonecraft of contradicting herself by holding both that virtue is universal and that women's virtue is relative to their capacity for motherhood, I suggest we look at some of her pronouncements, such as the following, more carefully. 'Speaking of woman at large, their first duty is to themselves as rational creatures, and the next, in point of importance, as citizens, is that which includes so many, of a mother'. ${ }^{13}$ Note the qualification Wollstonecraft is using: it certainly seems to indicate that she is not making a universal claim, and she could easily be read as commenting on the situation of her contemporaries, rather than trying to define womanhood in general. There is more: she talks of women having certain duties 'in the present state of things'. ${ }^{14}$ This also could be taken to indicate that the duties of motherhood are in part determined by social context. Women are not by their nature designed to be parents first and workers second, but at the time she is writing, it is what seems best for them, on the whole, to do. Another passage can be read in a similar fashion:

Mankind seems to agree that children should be left under the management of women during their childhood. Now, from all the observations I have been able to make, women of sensibility are the most unfit for this task, because they will infallibly, carried away by their feelings, spoil a child's temper. ${ }^{15}$ 
In this passage she is again tentative: this, we seem to agree on, she says. But agreement is by no means always represented by her as a sign of correctness: earlier in the book she refers to a general agreement that men look to the future and women to the present only. ${ }^{16}$ The passage just cited is also noteworthy for the following reason: Wollstonecraft is attempting to show that on men's own (p.205) standards of gendered division of labour, it is not the case that virtues should be gendered too. Even if women must do certain kinds of work because they are women, they will need to develop the same virtues and knowledge as men. So even though the consensus seems to her to be that women, when they are mothers, must fulfill certain duties, and even though Wollstonecraft herself, to some extent, seems to share this consensus, it does not follow, contrary to what I considered to be the case at the beginning of this section, that women need to develop different virtues. However, one must exercise care in drawing even this tentative conclusion, as Wollstonecraft does clearly state that she regards mothering as a peculiar duty of women assigned to them by nature, which does suggest that she thinks women's moral development, hence their virtues, may take a route determined in part by their biology.

In what follows, I would like to suggest that there are two strands in Wollstonecraft's concern for motherhood. One is simply that she regards the upbringing of infants, both physical and emotional, as crucial to the rearing of virtuous citizens. A second is that she is somewhat bound by the manifestations of motherhood in eighteenth-century England, and that these do not include the possibility of a good mother who does not nurse her own children. In Section 11.2 I will explore the first point, i.e. the ties between infant upbringing and good citizenship from the perspective of a French contemporary of Wollstonecraft's, Sophie de Grouchy. The second point will be addressed in Section 11.5.

11.2 De Grouchy on the Origins of Sympathy 
Sophie de Grouchy produced several pieces of writing that ought to be central to the study of republicanism's influence on moral and political philosophy. Her Letters on Sympathy, written in 1792 and published in 1798, together with her translation of Adam Smith's Theory of Moral Sentiments, offer the development of an original ethical theory that presupposes equality (of all, including women) and clearly entails a programme of social reform. What is particularly original about the theory is that, like the ethics of care, it regards mothering as paradigmatic of ethical behaviour. The Letters had until recently been all but forgotten but there has been a recent renewal of interest in de Grouchy's work. ${ }^{17}$ There are (p.206) two recent editions of the text in French, one also including some private letters and one critical edition, as well as a translation into English. ${ }^{18}$ Aside from the Letters, it is arguable that two articles published anonymously in the summer 1791 in the journal Le Républicain associated with de Grouchy and her husband Condorcet were in fact written or cowritten by de Grouchy. ${ }^{19}$ The articles present an early defence of republicanism in France, at a time when even Robespierre was not keen to adopt this appellation. ${ }^{20}$

The text I focus on in this section is de Grouchy's reaction to Smith's theory: her Lettres sur la Sympathie written in 1792 and published as an appendix to her 1798 translation of the Theory of Moral Sentiments. ${ }^{21}$ The text is divided into eight letters, the first of which explains that what prompted the author to write this commentary was the observation that Smith merely observed the existence of sympathy and of its 'principal effects' but did not attempt to find its origins, even though its discovery is bound to affect our understanding not only of its effects, but of its development and preservation. ${ }^{22}$ In the second and third letters, de Grouchy gives a detailed account of how sympathy comes into being, which puts her in a position to give an equally detailed account of how sympathy can be nurtured through education and the creation of good laws and institutions, which she does in the fourth letter. In lthe fifth, sixth, and seventh letters, she gives the details of a moral theory based on sympathy, and in the final letter, she reiterates the social implications of her claims, namely that human flourishing requires sensible laws and institutions and the lack of excessive social inequalities. 
Unlike Smith, who sees the sentiment of sympathy as a first principle, de Grouchy wants to trace it to a physiological first cause, that of the experience of (p.207) physical pain and pleasure. ${ }^{23}$ Pain and pleasure, she says, produce two kinds of effects in our bodies, one that is local, focused on the part of the body that is injured or pleasured, and one that is general, a feeling of well-being or discomfort that affects our entire bodies. This general feeling is such that it can be reproduced without directly experiencing the particular feeling, through remembering pain or pleasure, reflecting on it, or witnessing it in others. It is the latter, i.e. the experience of a general feeling of pain or pleasure on witnessing someone else's pain or pleasure, that she calls sympathy. Sympathy is therefore first directed towards physical pain, and from there it reaches out to moral suffering. Also, because it is first experienced as a result of feeling the repercussions of a particular person's pain in one's body, sympathy is at first directed at particular individuals. Only later, through the development of our faculties, in particular the mastery of abstraction, does it extend to the general condition of a class of people, or even the whole of humanity; only then does it become moral thinking. Because it means at first the we feel specific individuals' pains and pleasures as our own, sympathy necessitates a sort of dependence between people. De Grouchy represents codependence as a fact of life, a necessity, which we all experience first-hand as newborns, and then more or less, depending on our circumstances, throughout our lives. For de Grouchy, sympathy originates in the cradle, in the first relationship a human being is part of, that is, between a baby and its nurse. This first relationship not only teaches us to create a link between ourselves and other people, but to use this link in order to understand how they feel. It is also, she says, the first means by which we learn and develop.

The specific dependency on some individuals begins in the cradle. It is the first tie that attaches us to our fellows. It causes the first smiles, and the most regular smiles of a child are for his wet nurse; he cries when he is not in her arms and for a long time he loves to throw himself on this breast that satisfied his first needs, that made him feel the first sensations of pleasures, and where he began to mature and to form his initial life habits. ${ }^{24}$ 
(p.208) Because we are dependent on our nurse, she goes on to say, the thought that she might suffer is bound to affect us more than somebody else's suffering would. We feel the connection between her life and ours, and we are more alert to what affects her. Later in life, de Grouchy carries on, we develop individual sympathies for two kinds of people: those who can help us when we are in need, and those who share pleasures or interests with us. Again, there must be a link between these people and ourselves in order for us to be able to experience their suffering as our own. The ability to form such links is learned during our infancy and our survival and happiness later on depends on it. Individual sympathy, she argues, is also the basis for love and friendship. The link between two individuals who love each other must be strong enough that they are able to enjoy each other's happiness fully. She describes this link as a magnified interest for another, which makes us especially aware of what they feel. ${ }^{25}$ It is striking that to a large extent, de Grouchy pre-empts some of the concerns and arguments of care ethicists in her description of the relationship between an infant and her nurse. And what is particularly interesting from our point of view, is that she believes that this particular relationship is crucial for the growth and preservation of republican virtues. Mothering is not just one way of sustaining the republic while the men make the important decisions, but it is its bedrock, the only way in which it is at all possible for human beings to develop the sort of virtues required for a republic.

\subsection{Educating Sympathy and Preserving it Through Sensible Laws: A Republican Ideal In this section, I put together de Grouchy's and Wollstonecraft's views on the importance of sound educational laws and institution for the proper moral development of republican citizens. This paves the way for Section 11.4 in which I discuss the centrality of mothering practices and the education of infants in both their accounts.}


One thing that Enlightenment and republican thinkers of that period have in common is that they all believe that the good organization of society depends on making sure all citizens receive a sound education. Wollstonecraft and de Grouchy are both followers of Rousseau in that they believe that we must educate children from infancy, so as to assist the right development of their natural (p.209) inclinations to be good. For de Grouchy, this includes sympathy. ${ }^{26}$ In order to become more sympathetic, she says, we must become better at recognizing pain. This does not entail, of course, that parents should inflict pain on their children (though she does say that those who live harder lives tend to be more sympathetic than those who know only ease and pleasure). The role of parents and teachers is to familiarize children with suffering and develop their ability to recognize its symptoms. ${ }^{27}$ Also, in order to learn to move from individual to general sympathy, children must be taught abstraction. But education as it is practised in eighteenth-century France, she remarks, simply does not encourage abstract thinking. Learning by rote knowledge that one does not understand and only touching on the very basic scientific pursuits will not do.

Educational reform is needed, in content as well as method. Here again de Grouchy's position is very close to Wollstonecraft's who bemoans the fact that girls, in particular, are not taught to think abstractly and who also believes that the capacity for thinking beyond one's immediate circle is necessary for ethical thinking. 28 
Just as they believed in education's power to help human beings make the most of their natural sympathy, Wollstonecraft and de Grouchy shared many of their contemporaries' beliefs in the influence of laws and social institutions on human character. In particular, de Grouchy believed that we are naturally prone to sympathy and to developing moral beliefs based on this natural propensity, but that the most likely effect a law or institution will have is a perverting one. Therefore, the point of social reform is to ensure that laws and institutions do not actively prevent the natural development of human sympathy. This is not to say that de Grouchy's views about social reform are in any way lightweight. She perceives the laws and institutions in late eighteenth-century France as extremely harmful to the proper development of human morality. A few years into the revolution has not undone the fundamental social and economic inequalities that crippled her country. ${ }^{29}$ And one could argue that in very few parts of the world has this been achieved today. In fact, the example she gives of how social inequalities work against sympathy is one that would not be anachronistic a century later: that of the relationship between a powerful boss and his employee. The social distance between them means that they will not recognize each other (p.210) as someone who can experience pain as they do, and they will not feel sympathy for each other. As a result, the boss, de Grouchy says, will oppress his employee without any remorse, and the employee will not think twice before cheating his boss. Virtues, she says, need to be placed at more or less the same height if they are to find each other. So at the very least, laws and social institutions should not separate people from each other, at least not to the extent that they do not recognize human virtues in each other and are unable to feel sympathy for each other. ${ }^{30}$

More than this, de Grouchy feels that reform is needed to undo the damage created by previous bad laws and institutions. If sensible laws and non-dividing institutions would, in principle, suffice to ensure that human beings develop as they are supposed to, given how much harm has been done and how divided the people she sees around her are, much more work is needed. And there is no suggestion that such reform could be gentle either, as 'vicious institutions' have not only corrupted our nature, but driven us to 'idiotic blindness', which makes us 'accept as a law of necessity the chains one has become incapable of judging or breaking'. ${ }^{31}$ In this, her views are again very close to Wollstonecraft's who blames the viciousness of women on poor educational practices and laws which stunted their natural development.

\subsection{Wet-Nursing and Participation}

On de Grouchy's account, women's place in a society that values relationships would be very central: mothering infants-or wet-nursing-forms the very basis of the way we are linked to each other, and are able to flourish as members of a group. ${ }^{32}$ 
(p.211) In her picture, those who care for infants take centre stage in the first crucial step of moral development, that is, help an infant develop the seeds from which compassion will grow. Later on, mothers, fathers, and teachers are said to hold in their hands the future welfare of the next generation. ${ }^{33}$ But perhaps one ought to be suspicious of a proposal that makes the flourishing of society depend on women performing a job that is paid little or not at all and leaves no time for participating. A woman who has to stay home to look after babies, disabled, sick, or elderly relatives is obviously not in a position to participate in political life to the same extent as somebody who goes to work outside the home, keeps regular hours, and can take time off. The nature of caring is such that it does not include time off-and therefore carers tend to find themselves alienated from the public space and political participation. ${ }^{34}$

Women in the eighteenth century, whether mothers or wet nurses, certainly did not occupy a central place in the running of society, and no real attempt was made at making it so. But this does not mean that de Grouchy's proposal does not point in the direction of reforms that would enable the empowerment of care workers. 
One reason why women are traditionally associated with care is that they are the first carers for those who have not yet learned to care for themselves. A newborn without a mother or a female substitute would have been unlikely to survive in the eighteenth century. Yet, throughout Europe, the common practice for upper- and middle-class women and for working women in urban areas was to employ wet nurses, that is, women who had children of their own and produced enough milk to feed another at the same time. As far as some Enlightenment philosophers were concerned, wet-nursing was a crime committed by aristocratic women towards their children, out of laziness and vanity. Rousseau dedicates the first chapter of Emile, his highly popular and influential treatise on (p.212) education, to this very question. In a footnote he tells us that "The earliest education is most important and it undoubtedly is woman's work. If the author of nature had meant to assign it to men he would have given them milk to feed the child'. ${ }^{35}$ Rousseau argues that it is best that the child not be farmed out to a stranger, as there will be no one to ensure that the child is brought up in a healthy manner and one that does not endanger his moral development (I say 'his' because Rousseau is concerned here entirely with the education of men). On the other hand, because mothers are often unwilling to breastfeed their children, it may be best to choose a wet nurse carefully, and supervise her habits and diet closely. ${ }^{36}$ This is the solution he settles on for Emile: the mother is conveniently taken out of the equation, replaced by a nurse who is little more, in this case, than a feeding machine, thus leaving the tutor complete freedom in the upbringing of Emile. But this is not a practice Rousseau can recommend that all parents should follow. If their children do not benefit from the tutelage of someone such as he, Rousseau, it is better that the mother should step up and take charge of the feeding of her own infant. Not to do so would cause the following problem. Even if we choose a 'healthy nurse rather than a petted mother' to care for the infant, we run the risk of psychologically corrupting the child. A child who is suckled by a nurse will develop affections for someone he is taught to look down upon, while asked to respect a mother he has no affection for. The child thus is bound to develop ingratitude instead of more positive emotions.

Wollstonecraft's own argument in favour of mothers breastfeeding their own children is not dissimilar to Rousseau's. For her, morality begins at home, and a child who is sent out to a wet nurse will not learn what it is to be loved and to love in return. ${ }^{37}$ 
Her parental affection, indeed, can scarcely deserve the name, when it does not lead her to suckle her children, because the discharge of this duty is equally calculated to inspire maternal and filial affection: and it is the indispensable duty of men and women to fulfill the duties which give birth to affections that are the surest preservative against vice. Natural affection, as it is termed, I believe to be a very faint tie, affections must grow out of (p.213) the habitual exercise of a mutual sympathy; and what sympathy does a mother exercise who sends her babe to a nurse, and only takes it from a nurse to send to school? ${ }^{38}$

The character of future citizens, Wollstonecraft tells us, is formed in their childhood and in particular, their ability to care for each other and treat each other with respect is developed according to whether they experience affectionate relationships with their own carers. Being sent away twice, and later on expected to love and respect a mother who is but a stranger, is not conducive to the development of the kind of emotions that will later on bind citizens together. Thus, the mother in Wollstonecraft's picture is in charge of two crucial stages in a child's moral development (as well as being responsible for the child's health). The first is to 'inspire affection' in the very young child and infant, in such as way as to give him or her the capacity to love and be loved. Secondly, a mother's duty is to help those early affections grow into full-blown civic virtues. These two stages are tied to the mother, Wollstonecraft tells us; suckling does not merely help a child develop feelings of affection, but also inspires maternal love. A mother who does not feed her child, Wollstonecraft tells us, is less likely to learn to love her child and thereby to give him or her the necessary care and attention in later childhood. Though there is certainly some evidence that breastfeeding can be a bonding experience between mother and child, we also know that it is neither necessary nor sufficient. Mothers who bottlefeed (and indeed fathers) love their children just as much as those who breastfeed, and breastfeeding does not guarantee maternal love.

Another reason why Wollstonecraft is not willing to separate the duties of suckling an infant from those of educating a child is a contingent one.

Wollstonecraft believes, very plausibly, that natural affection is not of itself sufficient for parental love but that it must be strengthened by 'the habitual exercise of mutual sympathy'. Sympathy, she says, does not arise automatically, as soon as the baby is placed in his mother's arms. It requires the development of a relationship throughout its formative years. It requires that the child be cared for, consistently, and in a way that matches her progress-so hopefully by the same person or group of people who can develop a relationship with her and build on it over the years. The upper-class English practice of sending a child off to live with a nurse and then back home, and then to school clearly does not achieve this. One cannot receive a child at the age of three and expect to be loved by him or her instantly. A child's love and affection will grow through daily interactions, not simply because he or she is told that they are blood relations. 
(p.214) Wollstonecraft fails to consider a different kind of scenario, in which mother (or indeed father) and wet nurse work together to bring up the child with love and affection. Suzanne Necker, an outspoken defender of Rousseau's educational methods who gave up her attempts at breastfeeding her daughter after three months, described such an experience. Having experienced difficulties breastfeeding and suffered from depression as a result, she engaged a Flemish nurse to feed her baby. The nurse lived in the family home and Suzanne was able to work together with the nurse, and be part of every aspect of her daughter's infancy and childhood apart from her feeding. She contrasts this positive experience of mothering to the depression that followed from her inability to feed her daughter herself. ${ }^{39}$ But perhaps the fact that wet-nursing was a state-licenced occupation in France, while in England, the employment of wet nurses was more ad hoc, and therefore probably carried more risks, is relevant here. ${ }^{40}$

Wet-nursing seems to have been not only more regulated, but better established in France than it was in England, thereby allowing parents more flexibility in working together with the women who nursed their children. Moreover, wetnursing in France was not, as it was portrayed by its detractors, the privilege of the idle rich, of aristocratic women who did not want to make the effort to raise their own child, or to risk spoiling their looks by doing so, but common practice among the urban poor working women who could not afford to keep infants at home. ${ }^{41}$ Wollstonecraft may not have been fully aware of the social realities of the practice of breastfeeding in France, and this may have prevented her from seeing the possibility of a more rational and healthy relationship between nurse and mother such as the one displayed by the Necker household.

One last consideration as to why Wollstonecraft is so adamant that a mother must suckle her child is that she is attempting to derive a mother's right to citizenship from her duties, and obviously, the greater the duty, the clearer the right. Looking after babies, after all, is a 'grand duty' of women, and it belongs to them 'by nature'. ${ }^{42}$ The strong implication is that women's natural contribution to the common good is very high and that consequently they deserve to have a say in it! Were a woman's contribution to the raising of future citizens be replaceable, it would be less clear that they deserved the title of citizen. ${ }^{43}$ This (p.215) consideration, however, could be made to apply separately to any woman who feeds a child, whether or not her own, as well as to any person, male or female who takes care of a child's daily need. A wet nurse and a mother or father who looks after a child's early upbringing all contribute to the common good in the way Wollstonecraft describes, whether they care for the child alone or as a team. 
Because she insists on breastfeeding as central to this relationship, Wollstonecraft ties the actual mother to this process. If a wet nurse won't do, then the mother has to be the one who is responsible for making sure the child becomes a moral being, i.e. capable of caring for others. This is to be contrasted with Sophie de Grouchy's view which, because she does not insist on mothers feeding their own children, pre-empts that scenario. De Grouchy separates the various stages of a child's moral development. First, an infant must experience need and satisfaction at the hands of another. An infant must experience dependence. Later on, through the development of intellectual faculties, a child must learn to recognize suffering in others and understand how it can be relieved. But the two stages need not be supervised by a single person: indeed, one requires only a physical, and perhaps emotional presence, whereas the other demands a greater intellectual involvement. So for de Grouchy, a wet nurse suffices to the first stage, but the second requires also 'mothers, fathers and teachers'. ${ }^{44}$

By allowing that mothering can be practised by people who are not necessarily themselves mothers-of course, wet nurses had to have given birth in order to lactate, but in some cases, at least, the child had not lived, so they were not, technically mothers-she allows that the act be separated from the property of being a mother. ${ }^{45}$ This is a direct consequence of her looking for the physiological origins of sympathy. There is nothing physiologically special about a mother except that she produces milk and has a warm body with which to cuddle a baby. If another person can be found who has those same qualities, then there is no reason, on de Grouchy's account, why that person should not nurse a child. If Wollstonecraft did not come to the same conclusion it is not only because wet-nursing as she knew it was not a healthy practice and one that did not allow parents to develop close relationships with their children, but also because for her, the work of educating a child into citizenship is a civic duty, and thus must (p.216) have moral substance. She is not prepared to say that children's moral education depends, at first, on a purely physiological process.

\subsection{A Feminist Solution?}

Arguing that mothers must feed their own children, whether or not it is part of a programme to include women in politics or on the contrary to exclude them, certainly puts obstacles to their capacity to participate. ${ }^{46}$ De Grouchy's Letters on Sympathy offer a different solution to revolutionary French mothers simply because, unlike Rousseau or Wollstonecraft, she does not insist that mothers should breastfeed their own children. Unfortunately this is not, of itself, a solution to the systematic relegating of women to the kind of support work that leaves little room or opportunity for participation. Historically, wet nurses were lower-class women, so if their existence freed other women for activities that potentially could help them become citizens, it did nothing for women in general. 
One tentative reply to this problem draws on the idea that if children develop the right kind of relationships with their nurses, they will have the right kind of moral attitude towards them and will do their best to treat them with fairness and kindness later in life. But this does not solve the problem that care workers, while they are working, have little time or opportunity for participation. De Grouchy took care of her own nurse when she was too old to work, but this could not make up for lost opportunities to (try and) become a citizen. Wet nurses as a class remain alienated from public life.

A better solution begins with the thought that de Grouchy, by insisting that wet nurses can be responsible for a child's early moral development, demystifies motherhood. If an eighteenth-century mother could only be replaced by another lactating woman, the same is no longer true. Bottle-feeding and expressing milk mean that men, too, can feed infants, providing them with the same physical closeness and the same milk as women can. This means that we have a great deal more flexibility for redistributing the work of caring for infants. Two potential applications are: (1) the availability of workplace nurseries staffed by men and women who receive fair financial and social compensations for their work, and (2) an equally distributed parental leave, built on the expectation that fathers (p.217) and mothers will take equal time off work to perform the work of caring for infants. ${ }^{47}$ Under such conditions, it is possible to recognize the work of caring for infants as essential to the flourishing of society and not, at the same time, turn it into a means of oppressing women and/or lower-class people.

Wollstonecraft, perhaps because she tries to argue that the fact that they are mothers is a reason for granting women citizenship-if they are to educate future citizens they ought to participate in the city, and be educated as a citizen would-does not succeed in proposing full gender equality: women's citizenship remains conditional on their performing certain biological duties. De Grouchy who is less concerned with establishing women's rights to citizenship-perhaps because she feels that her husband Condorcet has already done this as well as it could be done-is not constrained by such considerations and paradoxically, it allows her to propose a less oppressive account of mothering.

\subsection{Conclusion}


De Grouchy's argument enables us to rethink the role of motherly duties in the republic, and share the burden of these more equally among citizens, so that women can have the same opportunity for political participation as men. Her perspective only differs from Wollstonecraft's in that she separates the duty of caring for infants, specifically providing them with the sort of warmth that will enable them later on to develop healthy relationships with other people, from the act of breastfeeding. This entails that parents have duties to ensure that they do their utmost to bring up their children properly, emotionally as well as physically, but that a mother's duty does not translate into an exclusive ability or responsibility to nurture. Under such circumstances, it is possible to argue, following Wollstonecraft in every other respect, that there should be no disparity in the requirements that men and women need to fulfil in order to be considered good citizens.

\section{Notes:}

( $\left.{ }^{1}\right)$ Melisa Matthes (2001), The Rape of Lucretia and the Founding of Republics (University Park, PA: Pensylvania State University Press); Anne Phillips (2000), 'Feminism and Republicanism: Is this a Plausible Alliance?', Journal of Political Philosophy 8 (2): 279-93.

$\left({ }^{2}\right)$ Some say this is the result of confusion, for instance, Alex Sager (2012), 'Political Rights, Republican Freedom and Temporary Workers', Critical Review of International Social and Political Philosophy 2: 1-23, whereas others believe that it is an inherent feature of republicanism that it should mix the two strands: Iseult Honohan (2002), Civic Republicanism (London: Routledge).

(3) Philip Pettit (1997), Republicanism (Oxford: Oxford University Press). Quentin Skinner (2008), 'Freedom as the absence of arbitrary power', in Cecile Laborde and John Maynor (eds) (2008), Republicanism and Political Theory (London: Blackwell); Honohan, Civic Republicanism.

( $\left.{ }^{4}\right)$ Honohan, Civic Republicanism.

$\left.{ }^{5}\right)$ It is not always clear that those who object to republicanism because of its emphasis on participation and the civic nature of virtue distinguish between the neo-Roman and the neo-Athenian branches. In any case, as Coffee argues in this volume, neo-Roman republicans need a stronger account of both participation and civic virtues.

( $\left.{ }^{6}\right)$ Mary Wollstonecraft (1994 [1792]), A Vindication of the Rights of Woman (Oxford: Oxford University Press), pp. 106, 122, 150-66. Note that

'Animadversions' is the title of ch. 5.

$\left({ }^{7}\right)$ Wollstonecraft (1994), p. 227.

$\left({ }^{8}\right)$ Wollstonecraft (1994), pp. 223, 278. 
$\left({ }^{9}\right)$ Wollstonecraft (1994), p. 76.

$\left.{ }^{10}\right)$ Wollstonecraft (1994), p. 86.

${ }^{(11)}$ Wollstonecraft (1994), p. 106.

$\left.{ }^{12}\right)$ In this volume, Coffee discusses the claim in one of the senses in which she uses it, virtue, is synonymous with an ability and willingness to submit to reason. See Coffee, this volume, Section 10.2.

$\left.{ }^{13}\right)$ Wollstonecraft (1994), p. 226 (my emphasis).

$\left.{ }^{14}\right)$ Wollstonecraft (1994), p. 227.

(15) Wollstonecraft (1994), p. 139.

${ }^{16}$ ) Wollstonecraft (1994), p. 100. This is an agreement of 'moralists' rather than mankind. But another reference to moralists' 'unanimous' agreement later on brings forth her approval (p. 280).

$\left({ }^{17}\right)$ Deidre Dawson (1991), 'Is Sympathy So Surprising? Adam Smith and French Fictions of Sympathy', in Sociability and Society in Eighteenth-Century Scotland, Eighteenth-Century Life 15 (1\&2): 147-62, argues that for Smith, sympathy is the basis of all human interaction, but that de Grouchy sees it especially as the basis of social reform. This makes the Letters on Sympathy especially relevant to care ethics: see Nel Noddings (2002), Starting at Home (Berkeley, CA: University of California Press), p. 22.

$\left({ }^{18}\right)$ Jean-Paul Lagrave (1993), Sophie de Grouchy, Lettres sur la Sympathie suivies des Lettres d'Amour à Maillat Garat (Montreal: Presses de l'Université du Québec); Marc-André Bernier and Deirdre Dawson (2010), Les Lettres sur la Sympathies (1798) de Sophie de Grouchy: philosophie morale et réforme sociale (Oxford: Voltaire Foundation); Karen Brown and James McClellan III (2008), 'Letters on Sympathy (1798), A Critical Edition', Transactions of the American Philosophical Society, New Series, 98: 4.

$\left({ }^{19}\right)$ Condorcet, Paine (1991), Aux Origines de la République 1789-1792. Volume III Le Républicain par Condorcet et Thomas Paine, 1791 (Paris: EDHIS).

$\left({ }^{20}\right)$ See Iain McLean (2011), 'The Paris Years of Thomas Jefferson', in Francis D. Cogliano (ed.), A Companion to Jefferson (London: Wiley-Blackwell), pp. 110-27; and Jean-Paul Lagrave (1989), 'L'influence de Sophie de Grouchy', in Pierre Crépel (ed.), Condorcet: Mathématicien, économist, philosophy, homme politique (Paris: Colloque International), p. 437.

$\left.{ }^{21}\right)$ All references are to Brown and McClellan III (2008), 'Letters on Sympathy'. 
$\left({ }^{22}\right)$ Brown and McClellan III, p. 108. There is a question as to whether de Grouchy misunderstood Smith's point, i.e. interpreted his desire to use sympathy as a theoretical starting point as the belief that its origins could not be found. However, the conclusions de Grouchy draws from her own discussion of the origins of sympathy are interesting enough that we can suppose that she, in fact, had reason to disagree with Smith that it was enough to start from sympathy without delving further into its genesis.

$\left.{ }^{23}\right)$ This is the source of two disagreements with Smith. First, de Grouchy disagrees with Smith that we feel less sympathy for physical pain than we do for moral pain, and secondly, that we feel little sympathy for pleasure (letter 4). De Grouchy's physiological claims are derived from the thought of Cabanis, her friend and the person to whom the letters are addressed ( $\left.C^{*}\right)$. What it amounts to is the belief that sensibility is the bridge between the body and the intellect, it is the starting point for all intellectual processes, and yet it originates in the brain. For Cabanis, the brain famously stood in relation to thinking as the stomach stood to digestion.

$\left({ }^{24}\right)$ Brown and McClellan III, pp. 117-18. Note that de Grouchy accepts the then-common practice of wet-nursing, so that although the first relationship involves maternal practice, or mothering, to use Ruddick's terminology, it does not have to involve a child's biological mother and could, in the twenty-first century, involve a father: Sarah Ruddick (1989), Maternal Thinking (Boston: Beacon Press), pp. 17, 51.

$\left({ }^{25}\right)$ This is strongly reminiscent of some characterizations of caring, for instance, Noddings (2002), Starting at Home, p. 15.

$\left.{ }^{26}\right)$ On how Wollstonecraft's theory of education drew on republican ideals, see Sandrine Bergès (2013), Wollstonecraft's A Vindication of the Rights of Woman (London: Routledge), pp. 30-5.

${ }^{27}$ ) De Grouchy cites her own experience of visiting the poor with her mother as a crucial part of her own education: Brown and McClelland III, p. 112.

$\left.{ }^{28}\right)$ Wollstonecraft (1994), pp. 200, 276.

$\left({ }^{29}\right)$ Though the Letters on Sympathy were published in 1798, she had already drafted them in 1792. 
${ }^{30}$ ) On this de Grouchy disagrees with Smith who thinks that not only can we feel sympathy for a king, but we feel more for a king than we do for an equal because of his greatness. De Grouchy points out that if we do feel sorry for a fallen king, it is because we assume that his previous state did not do enough to prepare him for his current pain, but that on the whole, his being so much above us grates against our natural sense of equality and disposes us to jealousy rather than sympathy.

${ }^{(31)}$ Wollstonecraft (1994), p. 175.

$\left.{ }^{32}\right)$ De Grouchy has very little to say about gender directly in the Letters on Sympathy. Only in the seventh of the eight letters does she address gender differences, and then only over a couple of pages. Having argued that it is the fundamental unreasonableness of the marriage institution that causes men to commit injustice on grounds of passion-forcing people to be monogamous, attaching shame to illegitimate births, not allowing couples to get to know each other before they marry, making divorce all but impossible for the majority of the population-she asks whether the same considerations may apply to women. Her answer is short and indirect. She quotes a passage from one of her husband's Academy of Science speeches, in which he describes the life and achievements of a British surgeon, and says in passing: 'the faults of women are the work of men, just as the vices of a people are the crimes of their tyrant'. But this need not mean that she is either conflating men and humanity, ignoring the particular plight of women, nor that she is not putting forward a feminist philosophy that highlights the way in which women's contribution to society, were it not stifled, would be beneficial to humanity in general. In private correspondence with Etienne Dumont, a few months before writing the Letters, she comments on a book that he has sent her that she is 'dreaming about the manner of bringing up a reasonable woman to live alongside men who will not be so with respect to women for a long time yet' (my translation). It seems that her preoccupations were not unlike Wollstonecraft's in that respect.

(33) 'Fathers, mothers, teachers, you have virtually in your hands alone the destiny of the next generation! Ah! How guilty you are if you allow to wither away in your children these precious seeds of sensibility that need nothing more to develop than the sight of suffering, the example of compassion, tears of recognition, and an enlightened hand that warms and coddles them!' Brown and McClelland III, p. 112.

${ }^{34}$ ) On this see Bergès (2015a) 'Is Motherhood compatible with political participation? Sophie de Grouchy's Care-based Republicanism', Ethical Theory and Moral Practice 18: 47-60.

$\left({ }^{35}\right)$ Jean-Jacques Rousseau (1966), Emile ou de L'Education (Paris: GarnierFlammarion), p. 37. 
${ }^{(36)}$ 'There can be no doubt about a wife's duty, but considering the contempt in which it is held, it is doubtful whether it is not just as good for the child to be suckled by a stranger', Rousseau (1966), p. 11.

$\left({ }^{37}\right)$ On this, see Eileen Hunt Botting's excellent discussion of the place of the family in Wollstonecraft's thought and her argument that Wollstonecraft, at the time she is writing both the Vindications, sees the home as the 'affective space within which citizens are effectively formed': Eileen Hunt Botting (2006), Family Feuds: Wollstonecraft, Burke, and Rousseau on the Transformation of the Family (Buffalo, NY: SUNY), p. 131.

$\left.{ }^{38}\right)$ Wollstonecraft (1994), p. 234.

( $\left.{ }^{39}\right)$ Madelyn Gutwirth (2004), 'Suzanne Necker's Legacy: Breastfeeding as Metonym', Eighteenth-Century Life 28 (2): pp. 19-20.

$\left({ }^{40}\right)$ Mary Jacobus (1992), 'Incorruptible milk: breastfeeding and the French revolution', in Sarah E. Melzer and Leslie W. Rabine (eds), Rebel Daughters: Women and the French Revolution (New York: Oxford University Press), p. 71.

(41) See Jacobus (1992), 'Incorruptible milk', p. 54.

$\left.{ }^{42}\right)$ Wollstonecraft (1994), p. 223.

$\left.{ }^{43}\right)$ Wollstonecraft (1994), p. 227.

(44) Brown and McClellan III (2008), 'Letters on Sympathy', p. 112.

$\left.{ }^{45}\right)$ This anticipates Sarah Ruddick's distinction between birthing and mothering. According to her, though birthing is always female, mothering can be practised by anyone regardless of their sex, and insists, further, that every person who practises mothering is adoptive in some way, even if they are mothering a child they gave birth to, as they had to make a choice, once that child was born, to care for it or not: Ruddick, Maternal Thinking, p. 51.

$\left.{ }^{46}\right)$ Interestingly, the question of whether or not women should breastfeed their own children did not help settle one way or the other the question of whether women should participate in politics. For some, such as Rousseau, women's nature as feeders did preclude their participation. But for others, such as Wollstonecraft (1994), p. 227, and Pierre Roussel (1977), Système Physique et Moral de la Femme (Paris: Vincent), women could only accede to political rights if they performed their duties as mothers, including breastfeeding! 
Wet-Nursing and Political Participation

$\left({ }^{47}\right)$ For a defence of these proposals see Anca Gheaus (2012), 'Is the Family Uniquely Valuable?', in Ethics and Social Policy 6 (2): 120-31; and Gheaus (2011), 'Arguments for non-parental care for children', Social Theory and Practice 37 (3): 483-509; Anca Gheaus and Ingrid Robeyns (2011), 'Equalitypromoting parental leave', Journal of Social Philosophy 42 (2): 173-91. 